\title{
Tandem AP-1-binding sites within the human $\beta$-globin dominant control region function as an inducible enhancer in erythroid cells
}

\author{
Paul A. Ney, Brian P. Sorrentino, Kevin T. McDonagh, and Arthur W. Nienhuis \\ Clinical Hematology Branch, National Heart, Lung, and Blood Institute, National Institutes of Health, \\ Bethesda, Maryland 20892 USA
}

\begin{abstract}
A powerful enhancer has been mapped to an 18-bp DNA segment located $11 \mathrm{~kb} 5^{\prime}$ to the human 6-globin gene within the dominant control or locus-activating region. This enhancer is inducible in $\mathbf{K 5 6 2}$ human erythroleukemia cells, increasing linked $\gamma$-globin promoter/luciferase gene expression to 170 -fold over an enhancerless construct. The enhancer consists of tandem AP-1-binding sites, phased $10 \mathrm{bp}$ apart, which are both required for full activity. DNA-protein binding assays with nuclear extracts from induced cells demonstrate a high molecular weight complex on the enhancer. The formation of this complex also requires both AP-1 sites and correlates with maximal enhancer activity. Induction of the enhancer may have a role in the increase in globin gene transcription that characterizes erythroid maturation. Enhancer activity appears to be mediated by the binding of a complex of proteins from the jun and fos families to tandem AP-1 consensus sequences.
\end{abstract}

[Key Words: AP-1; erythroid; inducible; enhancer; DCR; hypersensitive site]

Received October 5, 1989; revised version accepted March 13, 1990.

Human hemoglobins are tetramers composed of two pairs of globins, with one pair encoded by a gene within the $\alpha$-like cluster on chromosome 16 and the other pair encoded by a gene within the $\beta$-like cluster on chromosome 11. The $\beta$-gene cluster contains five functional genes and one pseudogene $\left(\epsilon,{ }^{G} \gamma,{ }^{A} \gamma, \psi-\beta, \delta\right.$, and $\left.\beta\right)$ that are distributed over $40 \mathrm{~kb}$ of DNA. Expression of the $\beta$ like globin genes is both tissue and developmentally stage specific. $\epsilon_{-}, \gamma$-, and $\beta$-globins are produced in embryonic, fetal, and adult erythroid cells, respectively. Globin genes at each developmental stage exhibit a marked increase in the level of expression during maturation of erythroid cells in contrast to diminished expression of most other genes (Karlsson and Nienhuis 1985; Stamatoyannopoulos and Nienhuis 1987).

Regulation of genes within the $\beta$-cluster occurs, at least in part, through interaction of trans-acting proteins with cis-acting regulatory elements (Dynan 1989; Mitchell and Tjian 1989). The promoters of the individual globin genes are tissue specific and may contribute to preferential expression during development (Lin et al. 1987; Rutherford and Nienhuis 1987). Intragenic elements and enhancers $3^{\prime}$ to the $\beta$ and ' $\gamma$ genes may also provide specificity (Behringer et al. 1987; Bodine and Ley 1987; Kollias et al. 1987; Trudel and Costantini 1987; Antoniou et al. 1988). The promoters and enhancers are marked by tissue-specific DNase I hypersensitive sites as assayed in isolated nuclei. Formation of such sites at the promoters is developmentally stage specific (Groudine et al. 1983; Tuan and London 1984). Several proteins have been shown to interact with sequence motifs within globin promoters and enhancers (de Boer et al. 1988; Gumucio et al. 1988; Mantovani et al. 1988a,b; Catala et al. 1989), including one such factor found only in erythroid cells, designated nuclear factorerythroid 1 (NF-E1) or globin factor-1 (GF-1) (Wall et al. 1988; Tsai et al. 1989|.

Study of naturally occurring deletion mutants of the $\beta$-globin cluster, the $(\gamma \delta \beta)$-thalassemias, suggested the existence of additional regulatory elements. An intact $\beta$ globin gene on a chromosome with a large upstream deletion was unexpressed, methylated, and in an inactive chromatin conformation (Kioussis et al. 1983). Major DNase I hypersensitive sites have been discovered $5^{\prime}$ and $3^{\prime}$ to the $\beta$-globin gene cluster, identifying regions that may contain these regulatory elements (Tuan and London 1984; Tuan et al. 1985; Forrester et al. 1986). Four erythroid-specific hypersensitive sites (HS I-HS IV), distributed over $20 \mathrm{~kb}, 5^{\prime}$ to the $\epsilon$-globin gene, are present in nuclear chromatin from erythroid cells of all developmental stages. A fifth site located even farther $5^{\prime}$ to the $\epsilon$ gene is also present in other hematopoietic cells. The sixth site (HS VI) is located $21.8 \mathrm{~kb} 3^{\prime}$ to the $\beta$ globin gene. Other $(\gamma \delta \beta)$-thalassemia mutations have been characterized (Curtin et al. 1985), including one that begins between HS I and HS II, $9.5 \mathrm{~kb} \mathrm{5}$ to the $\epsilon$ 
gene, leaving HS I and the entire cluster intact (Driscoll et al. 1989|. The $\beta$ gene on this chromosome was not expressed. Thus, the flanking HS sites, particularly those $5^{\prime}$ to the cluster, have emerged as potential regulatory elements that may control expression of the entire gene cluster in erythroid cells.

Direct experimental evidence for an important functional role of these regulatory elements was obtained in transgenic mice. In earlier studies the human $\beta$-globin gene was expressed at low levels in transgenic animals with substantial variation among strains derived from different founder animals (Magram et al. 1985; Townes et al. 1985; Kollias et al. 1986). Grosveld et al. (1987) assembled a 38-kb segment of DNA that included the human $\beta$-globin gene flanked by fragments containing the $5^{\prime}$ and $3^{\prime}$ major DNase I hypersensitive sites. Within the context of these regulatory elements, the human $\beta$ globin gene was expressed at a high level, equivalent to that of an endogenous mouse gene, and independent of chromosomal integration position. Because of its activity in transgenic mice and ability to confer erythroid specificity on heterologous promoters, Grosveld and his colleagues designated the $5^{\prime}$ region containing major DNase I hypersensitive sites as the dominant control region (DCR) (Blom van Assendelft et al. 1989; Talbot et al. 1989). An alternative designation, that of the locusactivating region (LAR), is based on the apparent ability of regulatory elements within this region to establish an active chromatin structure of the $\beta$-globin gene cluster (Forrester et al. 1987).

Progress has been made in localizing the functional components within the DCR/LAR, although the sequence motifs and interacting proteins required for DCR/LAR activity have not yet been defined. A 6.5-kb fragment containing the four erythroid-specific 5 ' HS sites has full activity in both transgenic mice and murine erythroleukemia (MEL) cells (Talbot et al. 1989). Forrester et al. (1989) have demonstrated that a $2.5-\mathrm{kb}$ fragment containing these sites also has full DCR/LAR activity in MEL cells. A fragment containing only HS II has been shown to confer tissue-specific, high-level expression on a $\beta$-globin gene in transgenic mice at $40-50 \%$ the level achieved with all four sites (Ryan et al. 1989). Furthermore, HS II contains a powerful enhancer, active in transient assays performed with human erythroleukemia cells (Tuan et al. 1989). Our results suggest that this enhancer is an important regulatory el- ement within the DCR/LAR. We have now mapped the HS II enhancer to an 18-bp segment. Its activity increases with induction of erythroid maturation in human erythroleukemia cells and depends on interaction with proteins that bind to tandem AP-1 consensus sequences within the 18 -bp element.

\section{Results \\ Localization of the HS II enhancer}

The distribution of the DNase I hypersensitive sites $5^{\prime}$ to the $\epsilon$-globin gene that mark the DCR are shown in Figure 1. HS II has been localized to $10.9 \mathrm{~kb}( \pm 0.1 \mathrm{~kb}) 5^{\prime}$ to the $\epsilon$-globin gene transcriptional start site (Forrester et al. 1987). In mapping the enhancer, we initiated our studies with a 1455-bp KpnI-BglII fragment containing HS II. We designated the first nucleotide within the KpnI site as nucleotide 1, making the first nucleotide within the BglII site nucleotide 1455. A 732-bp HindIII-BgIII fragment (nucleotide 723-1455) has been shown to contain the enhancing activity of HS II (Tuan et al. 1989). We utilized a larger KpnI-BgIII fragment to include another hypersensitive site present in nuclei of erythroleukemia cells (Forrester et al. 1987). Our reporter plasmid consisted of a $-260 \gamma$-globin gene promoter, in a pUCbased plasmid, linked $5^{\prime}$ to the coding sequence of the luciferase gene (DeWet et al. 1987). Mutants of the HS II fragment or oligonucleotides were subcloned 5 ' of the chimeric $\gamma$-globin promoter/luciferase gene and assayed for enhancing activity. Transient assays were performed in $\mathrm{K} 562$ cells, a human erythroleukemia cell line (Lozzio and Lozzio 1975). K562 cells express the $\epsilon$ - and $\gamma$-globin, but not $\beta$-globin genes and therefore have been used as a model for the embryonic/fetal stage of development (Rutherford et al. 1981; Dean et al. 1983). Addition of chemicals such as hemin to K562 cells induces an erythroid phenotype, as manifested by increased expression of globin and other erythroid-specific genes (Hoffman et al. 1980; Dean et al. 1983; McGinniss and Dean 1985; Bartha et al. 1987).

The $5^{\prime}$ and $3^{\prime}$ truncation mutants of the HSII fragment were made by exonuclease III digestion. These mutants were cotransfected into K562 cells with a B19 promoter/ chloramphenicol acetyltransferase (B19-CAT) reporter construct as an internal control. Relative activity was derived by dividing the luciferase activity of a given mu-

Figure 1. Position of DNase I hypersensitive sites flanking the human $\beta$-like gene cluster. The five functional genes of the human $\beta$-like gene cluster, distributed over $\sim 40 \mathrm{~kb}$, are shown. Four developmentally stable erythroid-specific DNase I hypersensitive sites are located $5^{\prime}$ and one $3^{\prime}$ of the cluster. We have used the nomenclature of Tuan et al. (1985). Distance in kilobases from the $\epsilon$-globin gene (HS I-HS IV) or the $\beta$ globin gene (HS VI) is given in parentheses. HS V (not shown/ is not erythroid specific. The 1455-bp HS II-containing fragment used in our studies is expanded to show the relative position of several restriction sites.

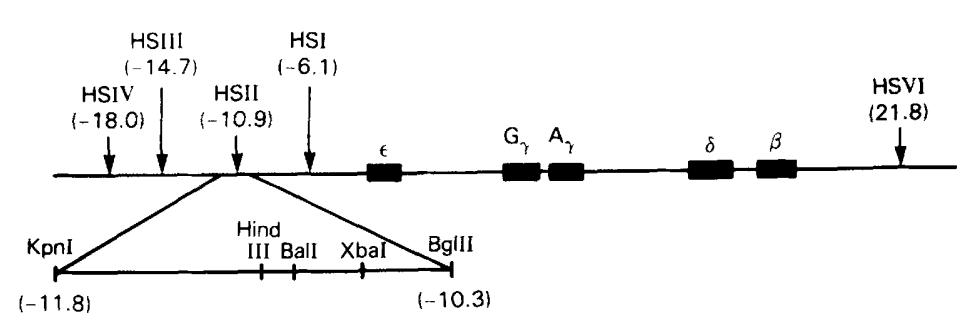


tant by that of the enhancerless reporter plasmid, each having been corrected for transfection efficiency with the internal control. Study of the initial set of truncation mutants demonstrated that the enhancer was within a 174-bp fragment (807-981) (Fig. 2). A second series of closely spaced truncation mutants established the $3^{\prime}$ border of the enhancer at nucleotide 916 (data not shown/. To define the $5^{\prime}$ boundary of the enhancer, a series of 5 oligonucleotides were synthesized and subcloned into the expression plasmid (Fig. 3). Each of these had full enhancer activity, including the smallest of only 20 bp (896-916).

DNase I protection assays were done to identify regions of sequence-specific, DNA-protein interactions by utilizing a restriction fragment extending from nucleotide 723 to 977 as probe. With K562 nuclear extracts, a very prominent footprint was present on both strands directly over the functionally defined minimal enhancer (Fig. 4). This footprint was also present with HeLa cell nuclear extract. Nuclear extracts from uninduced and hemin-induced $\mathrm{K} 562$ cells gave similar footprinting patterns; however, the footprint over the enhancer appeared at lower concentrations of induced nuclear extract. Uninduced and induced K562 nuclear extracts were standardized by comparing their Spl-binding activity in a gel mobility-shift assay, which was equivalent at equivalent protein concentrations (data not shown). At higher con- centrations of K562 or HeLa cell nuclear extract, another footprint, flanked by sites of increased DNase I sensitivity, appeared from $\sim 10-30$ bp $5^{\prime}$ of the enhancer footprint. However, this region and other sequences outside the minimal enhancer were not necessary for enhancer activity and were not studied further.

To verify that no other sequences within the KpnIBglII HS II fragment had enhancer activity, we scrambled 31 nucleotides (900-931) while leaving the remainder of the fragment unaltered. This mutated fragment was designated HS II enh ${ }^{-}$. A $16-\mathrm{bp}$ stretch of the 20 -bp enhancer $(901-916)$ was mutated by this construction. Our earlier analysis of 3 ' truncation mutants indicated that sequences between 916 and 931 , also rearranged in this construction, had no role in the activity of the enhancer. The HS II enh- fragment had no activity in transient assays in $\mathrm{K} 562$ cells (Fig. 5). The footprint present over the active enhancer was not present when the corresponding restriction fragment from HS II $e n h^{-}$ was used as a probe (Fig. 4B). When the same constructs were transfected into HeLa cells, the HS II enhancer had modest activity (relative activity: no $\mathrm{HS}$ II, $1.0 \pm 0.1$; HS II (1455 bp), $2.8 \pm 0.8$; HS II (46 bp), $3.9 \pm 0.1$; HS II enh-, $0.7 \pm 0.1$. In summary, our data establish that a 20 -bp segment (896-916) has the full enhancing activity of HS II and that no other sequences within the KpnI$B g$ III fragment contribute to this activity.

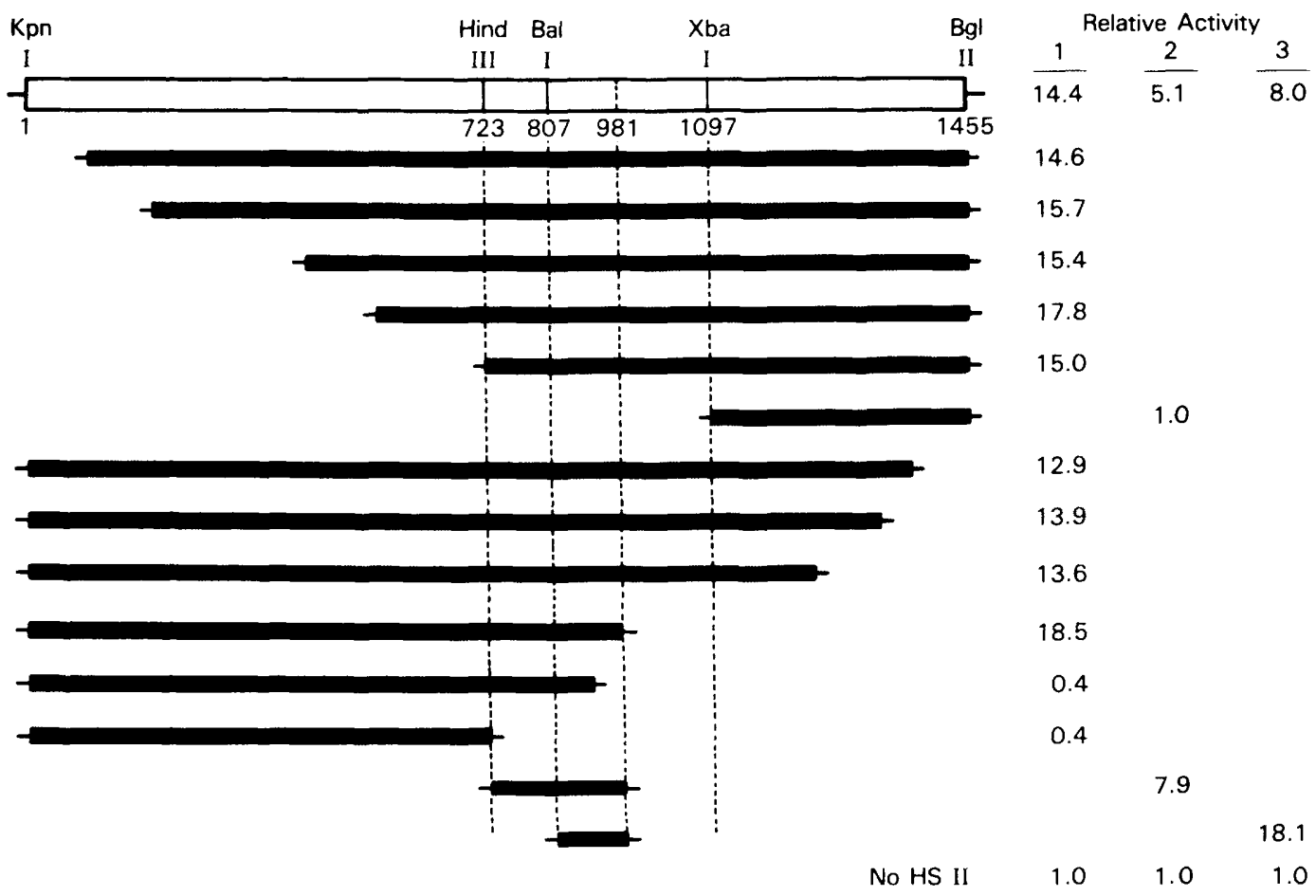

Figure 2. Enhancing activity of HS II truncation mutants. The KpnI-BgIII fragment containing HS II used in our studies is shown at top. The first nucleotide of the KpnI site is 1 (7764 in GenBank) and the first nucleotide of the BglII site is 1455. Truncation mutants 5' and $3^{\prime}$ of HS II are depicted below. The results from three separate experiments are shown at right. Relative activity was determined by comparing the luciferase activity of a given mutant to that of an enhancerless reporter plasmid (no HS II). The relative activity of truncation mutants in each experiment should be compared to wild type from the same experiment. Cotransfected B19-CAT reporter construct served as an internal control in all experiments. Each mutant was tested at least twice, and the relative activities shown are representative. 
Figure 3. Localization of the HS II enhancer. Synthetic oligonucleotides were used to precisely define the $5^{\prime}$ border of the enhancer. The results from two experiments are shown at right. Relative activity was determined by comparison to an enhancerless reporter plasmid (no HS II). Cotransfected B19-CAT served as an internal control in all experiments. Every oligonucleotide was tested at least twice, and the relative activities shown are representative.

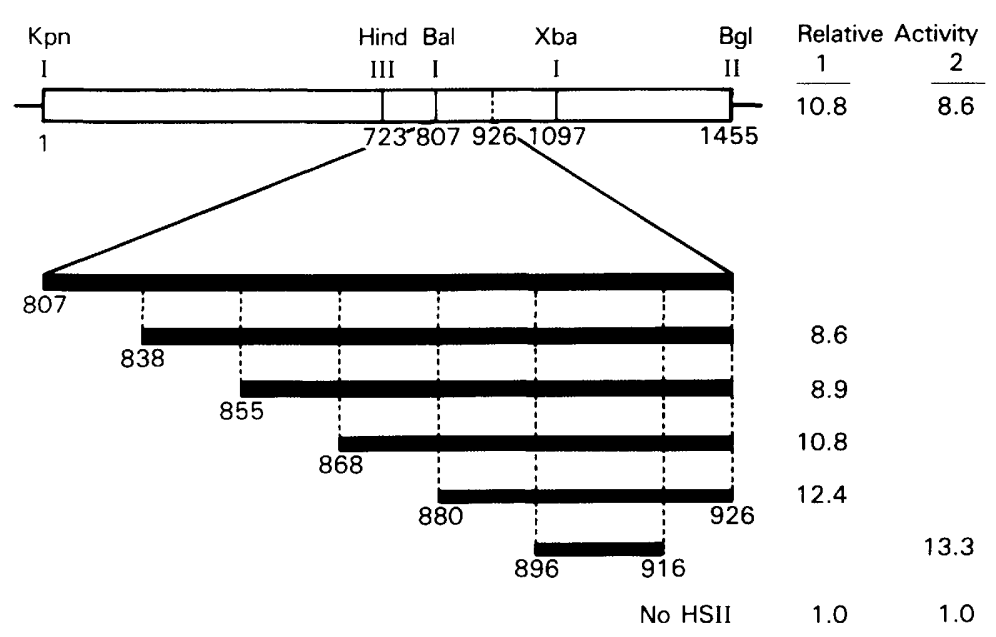

tracts and to allow comparison of transcription factors between extracts (Jackson et al. 1989).

By use of the enhancer as probe, nuclear extract from induced K562 cells generated a broad, highly retarded band (lane 3, bracket a). Extract from uninduced cells, at two-thirds the concentration, generated a cluster of several less retarded bands (lane 4, bracket b). The broad, highly retarded band seen with induced nuclear extract could be reproduced by increasing the concentration of uninduced to $3 \frac{1 / 3}{3}$ that of induced nuclear extract (lanes 4-8). Conversely, several less retarded bands were generated by dilution of induced nuclear extract (lanes 9-13). These results suggested that in assays with induced nuclear extract or high concentrations of uninduced nuclear extract, two or more protein molecules were binding to the enhancer. These data raised the possibility that enhancer activity is dependent on formation of a multimeric protein complex. The titrations of uninduced and induced nuclear extracts (Fig. 7A) show that formation of the protein complex is concentration dependent but do not establish the identity of the proteins required for full activity of the enhancer with hemin induction. Indeed, the pattern of bands observed at low concentrations of induced and uninduced nuclear extracts are not identical. Induction may be accompanied by modification (e.g., phosphorylation) of proteins binding to the enhancer or the appearance of new proteins that participate in complex formation.

The enhancer contains two AP-1-binding sites, both of which are required for full activity

Inspection of the 20-bp enhancer revealed tandem, direct 9-bp repeats, each containing a full match to the 7-bp activating protein-1 (AP-1) consensus binding sequence, TGAGTCA (Fig. 8A) (Jones et al. 1988). AP-1 was first identified as the product of the c-jun gene (Bohmann et al. 1987), but now the designation AP-1 refers to the jun and fos families of proteins that bind as dimers to the AP-1 consensus sequence (Curran and Franza 1988). We used DNA fragments containing authentic AP-1-binding sites as competitors in gel mobility-shift assays (Fig. 7B). 


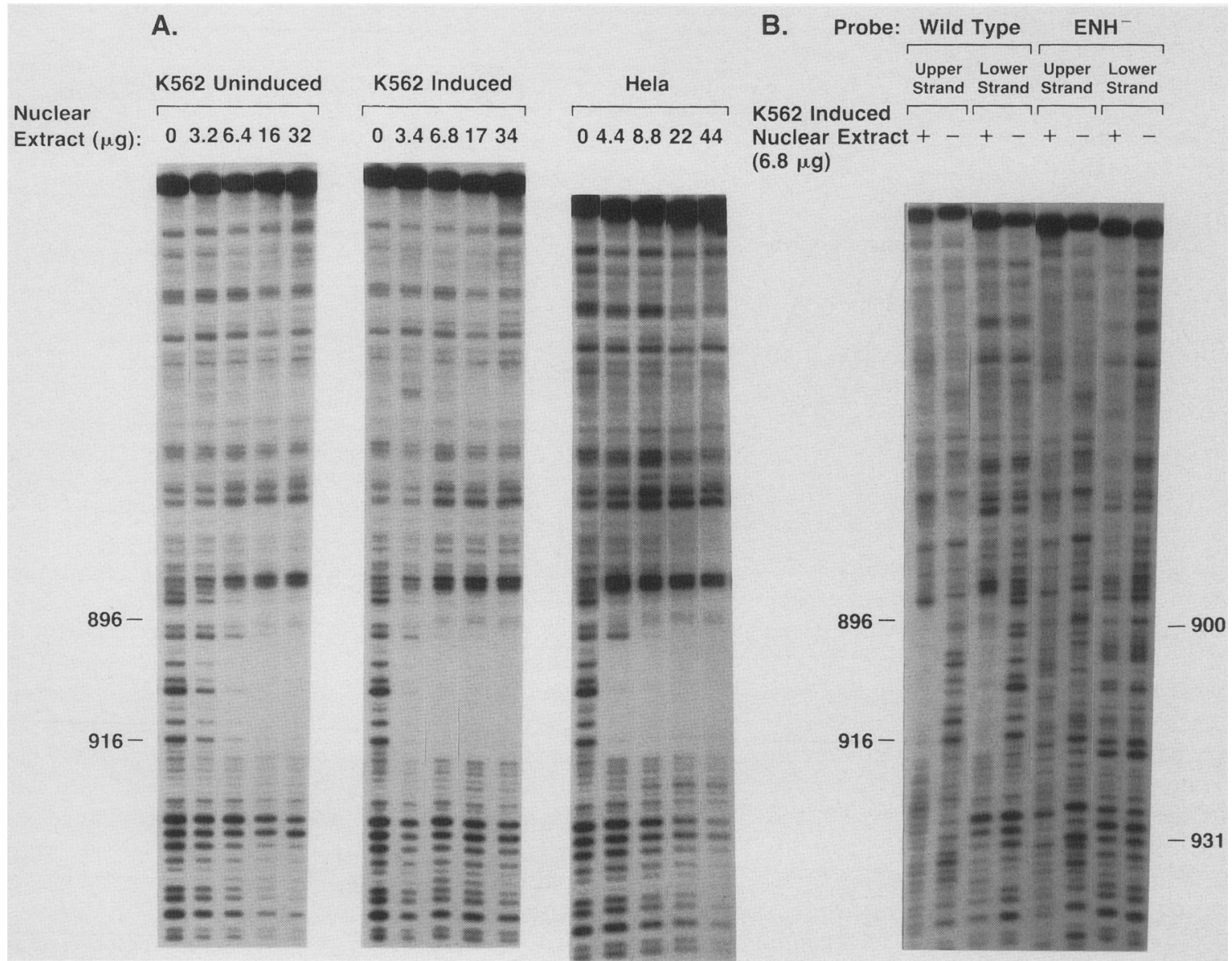

Figure 4. DNase I protection assay of HS II. (A) A 254-bp wild-type fragment (723-977), with enhancing activity equivalent to the 1455-bp KpnI-BgIII fragment, was used as probe. Individual reactions contained increasing amounts (left to right) of uninduced and induced K562 and HeLa cell nuclear extract, as indicated. (Left) Coordinates mark the functionally defined minimal enhancer. $(B)$ Fragments of 254 bp (723-977), containing the wild-type enhancer or a scrambled enhancer (enh ${ }^{-}$; see Fig. 5), were used as probe. DNase I protection assay was performed on upper and lower strands. Individual reactions contained $6.8 \mu \mathrm{g}$ of hemin-induced K562 cell nuclear extract $(+)$ or no nuclear extract $(-1$, as indicated. Coordinates mark the minimal enhancer $(1 e f t)$ and the scrambled enhancer (right). Sequences outside the scrambled enhancer (723-899 and 932-977) are wild type.

The retarded bands observed in extracts from both uninduced and induced K562 cells with the HS II enhancer probe were effectively competed by three known AP-1binding sites (Angel et al. 1987; Lee et al. 1987). In contrast, no competition was observed with a fragment containing authentic binding sites for NF-E1, the erythroidspecific factor (Tsai et al. 1989).

To study binding by members of the iun and fos families to the enhancer further, gel mobility-shift assays were performed with erythroid and nonerythroid nuclear extracts and with in vitro-synthesized c-Jun and c-Fos (Fig. 7C). Consistent with the ubiquitous distribution of members of the $j u n$ and fos families, the HS II enhancer was bound by proteins present in all nuclear extracts tested (lanes 1, 3, 5, 7, and 9). When present, the less retarded bands (b) comigrated with a single AP-1 site probe (lanes $2,4,6,8$, and 10 ), suggesting that they represented binding to one AP-1 site and that the highly retarded band (a) represented binding to both AP-1 sites in the enhancer. The latter was supported by in situ phen- anthroline/copper footprinting of the highly retarded band seen with induced K562 nuclear extract. A footprint was apparent in the region 893-918, encompassing both AP-1 sites (data not shown).

In vitro-synthesized c-Jun/c-Fos heterodimer also bound the enhancer and migrated adjacent to one of the less retarded bands seen with HeLa cell nuclear extract and slightly above those seen with uninduced K562 nuclear extract. This band corresponded to single AP-1 site occupancy (lanes 11-16). By increasing the concentration of the c-Jun/c-Fos heterodimer, a band can be elicited that comigrates with the highly retarded band seen with nuclear extracts (data not shown). c-Jun or c-Fos alone shows little or no binding to the enhancer, respectively. These results demonstrate clearly that members of the jun and fos families are able to bind the HS II enhancer. We interpret these data to suggest that the comigrating band formed in extracts of HeLa cells is a c-Jun/c-Fos heterodimer. The absence of this band in extracts of uninduced $\mathrm{K} 562$ cells suggests that the complex 
Figure 5. Mutation of enhancer sequence within HS II eliminates all activity. Thirty-one bp (900-931) of the full HS II fragment (1455 bp) was scrambled, including 16 of the $20 \mathrm{bp}$ of the minimal enhancer. This construct was designated HS II $e n h^{-}$. The location of the scrambled sequence within HS II $e n h^{-}$is expanded. The enhancing activity of this construct was compared to wildtype HS II and to an enhancerless reporter plasmid (no HS II), as shown at bottom. Cotransfected B19-CAT served as an internal control. On repetition, this experiment gave virtually identical results.

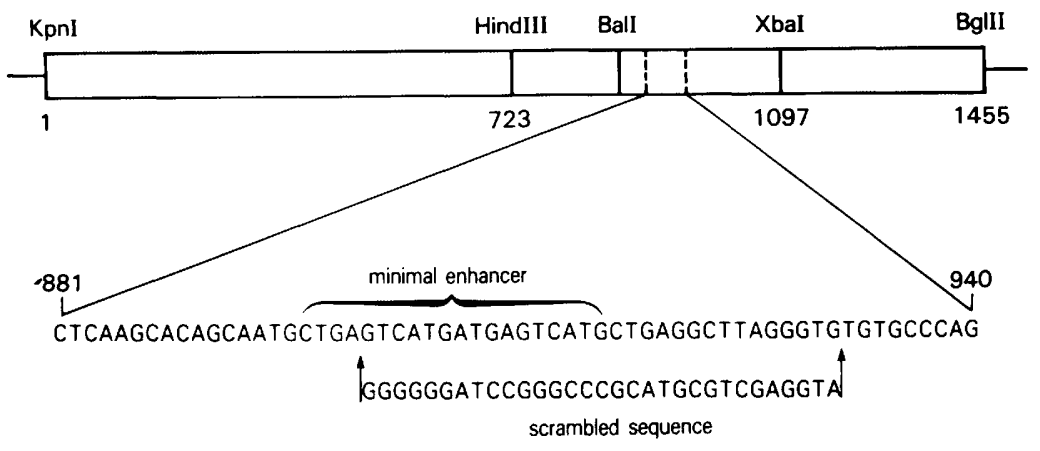

\begin{tabular}{ll} 
Relative Activity & \\
HSII $(1.5 \mathrm{~kb})$ & 8.6 \\
HSII ENH & - \\
No HSII & 0.4 \\
\hline
\end{tabular} binding the enhancer in uninduced K562 cells is not the same as that in HeLa cells but represents either a modification or a different dimer from the Jun/Fos dimer families.

To determine the contribution of the individual AP-1binding sites to enhancer function and protein complex formation, the enhancer was scanned with mutants in 3-bp intervals (Fig. 8A). These triplet scanning mutants were assayed for activity in uninduced and induced K562 cells. Mutation of either AP-1 consensus sequence (mutants $1-6$ ) caused a loss in activity to $20-58 \%$ of that observed with the wild-type enhancer in the uninduced state and $6-34 \%$ of that seen in the induced state (Fig. 8B). Mutant 7, which falls outside both AP-1 consensus sequences, was as active as the wild-type enhancer in the uninduced state and slightly less active in the induced state. Those mutants with the lowest activity also tended to have the lowest inducibility, although inducibility per se was preserved with even the least active mutants. However, the activity of the least active mutants of either AP-1 site (mutants 2, 3, and 5) was far below that of the wild-type enhancer in the induced state. These data lend support to our hypothesis that complex formation involving both AP-1 sites is necessary for full enhancer activity.

The functional activity of the enhancer mutants cor- related quite well with their ability to form the highly retarded multimeric complex in a gel mobility-shift assay with induced K562 nuclear extract (Fig. 9). With mutants of either AP-1 site (mutants 1-6), the band corresponding to single-site occupancy (b) predominated. In contrast, the wild-type enhancer and mutant 7 , which leave both AP-1 consensus sequences intact, generated the band corresponding to occupancy of both AP-1 sites (a). Gel mobility-shift assay of the enhancer mutants with HeLa cell nuclear extract gave a very similar pattern, but the bands corresponding to single-site occupancy (b) are closer together than with induced K562 nuclear extract. These results establish that formation of the multimeric complex land full activity of the enhancer) requires both AP-1 sites.

\section{Discussion}

The enhancer within HS II has been localized to two tandemly repeated AP-1 consensus binding sites within an 18-bp segment. These binding sites are phased $10 \mathrm{bp}$ apart, placing them on successive helical turns of the DNA molecule. An unexpected finding was the increase in enhancer activity as human erythroleukemia cells matured in response to chemical induction. These observations led us to propose a physiological role for the enhancer in contributing to the increase in globin gene

Table 1. The HS II enhancer is inducible

\begin{tabular}{|c|c|c|c|c|c|c|c|c|}
\hline & \multicolumn{4}{|c|}{ Uninduced } & \multicolumn{4}{|c|}{ Hemin induced } \\
\hline & $\begin{array}{l}\text { luciferase } \\
\text { activity } \\
\text { (per } 1000 \\
\text { light units) }\end{array}$ & $\begin{array}{l}\text { CAT } \\
\text { activity } \\
\text { (per } 1000 \\
\text { cpm) }\end{array}$ & $\begin{array}{l}\text { luciferase/ } \\
\text { CAT }^{2}\end{array}$ & $\begin{array}{l}\text { relative } \\
\text { activity }\end{array}$ & $\begin{array}{l}\text { luciferase } \\
\text { activity } \\
\text { (per } 1000 \\
\text { light units) }\end{array}$ & $\begin{array}{l}\text { CAT } \\
\text { activity } \\
\text { (per } 1000 \\
\text { cpm) }\end{array}$ & $\begin{array}{l}\text { luciferase/ } \\
\text { CAT }^{2}\end{array}$ & $\begin{array}{l}\text { relative } \\
\text { activity }\end{array}$ \\
\hline No HS II & 2.9 & 10.5 & 0.4 & 1.0 & 3.3 & 22.8 & 0.2 & 0.4 \\
\hline HS II (1455 bp) & 38.4 & 12.5 & 4.0 & 10.8 & $746^{\mathrm{b}}$ & 20.5 & 42.7 & 115 \\
\hline HS II (46 bp) & 73.0 & 21.0 & 4.0 & 10.9 & $1,527^{b}$ & 27.1 & 63.4 & 171 \\
\hline HS II $e n h^{-}$ & 1.1 & 10.7 & 0.1 & 0.4 & 4.0 & 47.4 & 0.1 & 0.2 \\
\hline No extract & 0.1 & 3.0 & - & - & 0.1 & 3.0 & - & - \\
\hline
\end{tabular}

${ }^{2}$ Luciferase/CAT activity ratio, after subtracting background (no extract) from each.

bSamples giving values $>100,000$ light units were diluted, reassayed, and corrected for dilution by the appropriate factor. These represent corrected values. 


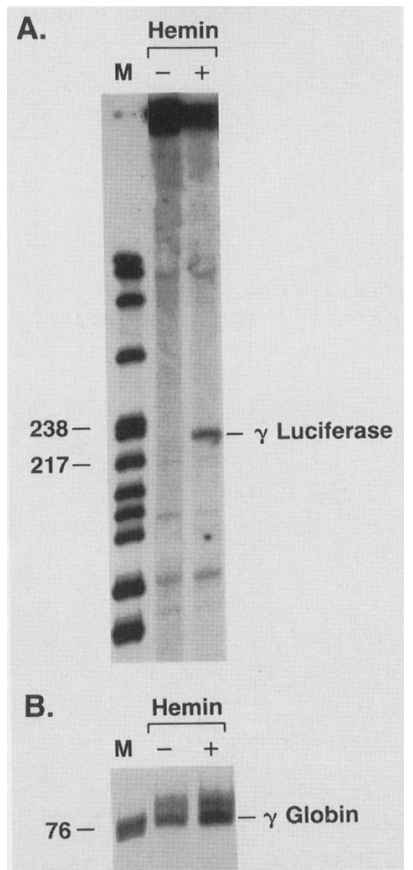

Figure 6. Primer extension analysis of chimeric $\gamma$-globin/luciferase transcripts. K562 cells were transiently transfected with an HS II enhancer (46 bp) containing reporter plasmid and induced with $20 \mu \mathrm{M}$ hemin $(+)$ or left untreated $(-)$. (A) Molecular weight marker is shown in the leftmost lane, with the 238and $217-\mathrm{bp}$ bands indicated. Correctly initiated $\gamma$-globin/luciferase mRNA gives a 228-bp extension product. Minor bands present in the uninduced and induced lanes were also seen with RNA from untransfected K562 cells and represent artifacts from the primer extension assay. $(B)$ Molecular weight marker is shown in the leftmost lane, with the 76-bp band indicated. Correctly initiated endogenous $\gamma$-globin mRNA gives a 76 -bp extension product.

expression that is characteristic of erythroid cell maturation. This enhancer seems likely to be one of several regulatory elements, marked by the four $5^{\prime}$ HS sites, that are required for tissue-specific, high-level expression of the individual globin genes in erythroid cells.

The enhancer was mapped by utilizing short-term (transient) assays of unintegrated reporter genes, but it is also active when stably integrated. The role of the enhancer in the induction of globin genes was first suspected in our laboratory when we observed that the 1455-bp HS II fragment was required for induced expression of a stably integrated ${ }^{\mathrm{A}} \gamma$-globin gene in K562 cells, as reflected by the concentration of correctly initiated mRNA (Sorrentino et al. 1990). The 46-bp enhancer was shown to confer inducibility, whereas an integrated $\mathrm{A}_{\gamma}$ globin gene linked to the HS II $e n h^{-}$fragment was uninducible. In fact, the enhancer has been shown to be required for full DCR/LAR activity in K562 cells. A construct of fragments, containing sites IV, III, and II, allowed a linked $\mathrm{A}_{\gamma}$-globin gene to be expressed at the same level as an endogenous ${ }^{A} \gamma$-globin gene in K562 cells, whereas a ${ }^{\mathrm{A}} \gamma$-globin gene in a construct with HS
IV, HS III, and HS II $e n h^{-}$was expressed at a significantly lower level (Sorrentino et al. 1990).

Our results in $\mathrm{K} 562$ cells have been obtained by study of the $\gamma$-globin gene or its promoter. Others have reported modest induction of the $\gamma$-globin promoter in the absence of the HS II enhancer but in $<50 \%$ of stably transfected K562 clones (Kioussis et al. 1985; DonovanPeluso 1987). A hybrid $\gamma / \beta$ promoter linked to the $\beta$ globin gene has also been shown to be modestly inducible in K562 cells without the HS II enhancer (Lin et al. 1987). The human $\beta$-globin gene linked to a nonglobin promoter, or the promoter linked to a nonglobin gene stably integrated into MEL cells, is variably expressed but most often highly inducible without the HS II enhancer (Chao et al. 1983; Wright et al. 1983, 1984). Inducibility of the $\beta$-globin promoter depends on the presence of a recognition site for a CCAAT-binding protein (CP1) and one of two NF-El sites in the $\beta$-globin promoter (de Boer et al. 1988). The basis for this difference in the requirement for the HS II enhancer for globin gene inducibility between mouse and human erythroleukemia cells is uncertain at present. Perhaps there is redundancy in regulatory mechanisms, as has been observed in other systems. Experiments are in progress to define the function of the enhancer and its effect on human globin gene expression in transgenic mice.

The iun and fos families of proteins, collectively referred to as AP-1 (Curran and Franza 1988), share a highly homologous domain composed of a basic segment and a leucine zipper (Gentz et al. 1989; Kouzarides and Ziff 1989; Ransone et al. 1989; Turner and Tjian 1989). Members of the iun family bind with high affinity to DNA as a heterodimeric complex with members of the fos family (Halazonetis et al. 1988; Cohen et al. 1989). The dimer binds to a single AP-1 site. We therefore infer that the tandem sites that make up the HS II enhancer bind two dimers forming a multimeric complex of at least four polypeptide chains.

The iun and fos families are expressed ubiquitously, although individual genes may be differentially expressed in specific cell types. This has been shown for the jun genes in the tissues of adult mice (Hirai et al. 1989|. Similarly, the enhancer was bound by proteins expressed in all cell types tested, but the composition of the complex binding to the enhancer need not be the same in extracts from different cell types. Consistent with this, on gel mobility-shift assay, we found differences in mobility between uninduced K562 and HeLa cell nuclear extracts relative to in vitro-synthesized c-Jun/c-Fos heterodimer. We also found differences between induced $\mathrm{K} 562$ and HeLa cell nuclear extracts when single-site occupancy bands were generated by enhancer mutants with one AP-1 site ablated.

Tuan et al. (1989) have reported that the HS II enhancer is erythroid specific. In our experiments, the enhancer gave only a threefold increase in reporter gene expression in HeLa cells but more than a 100-fold increase in induced $\mathrm{K} 562$ cells. The promoter in our experiments may have contributed to this tissue specificity, although Tuan et al. (1989) reported tissue specificity of 
Ney et al.

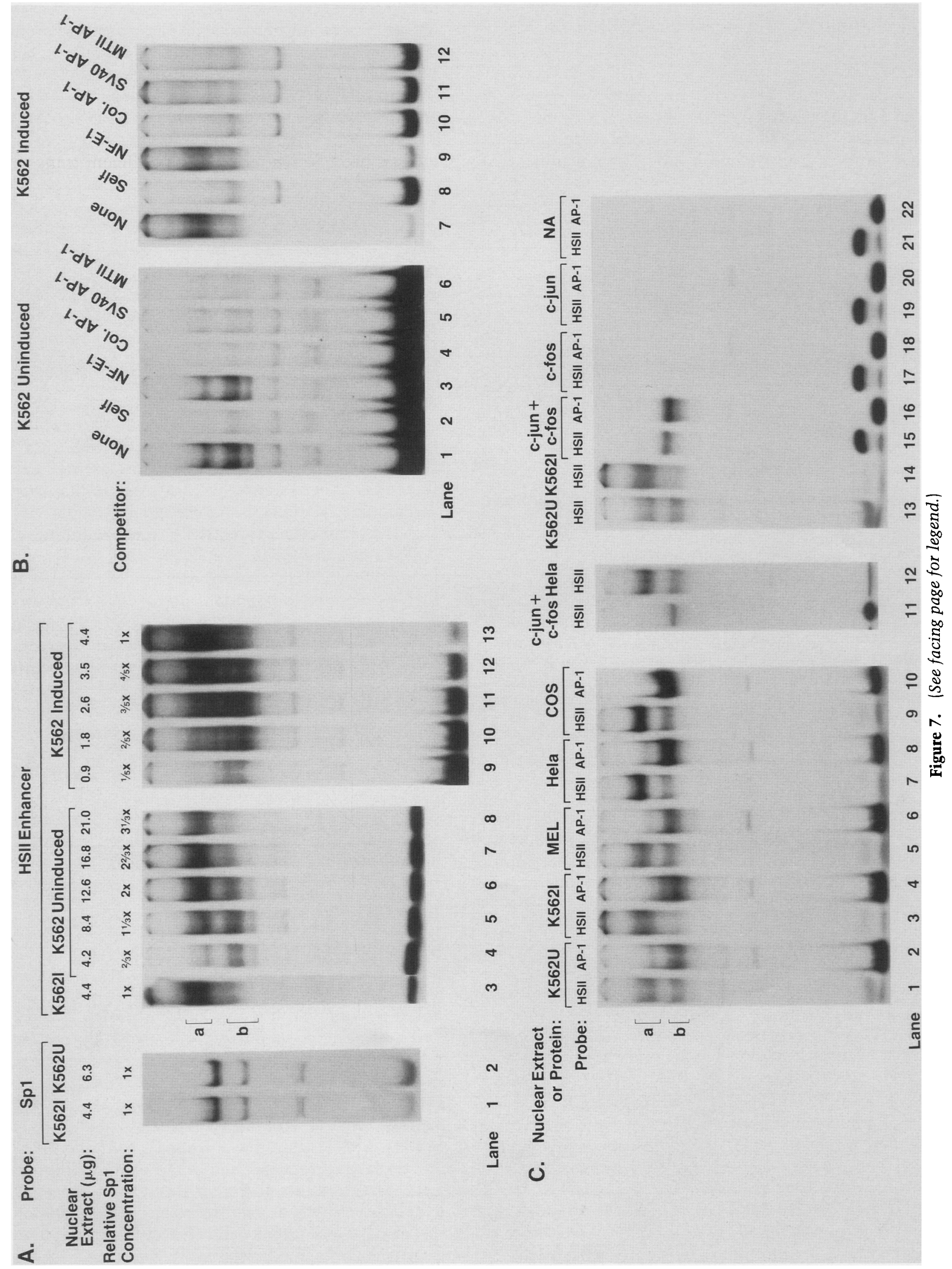


the enhancer with a nonglobin promoter. In transgenic mice, an 882-bp fragment of HS II, which contains the enhancer, has been reported to be sufficient for highlevel, tissue-specific expression of the $\beta$-globin gene (Curtin et al. 1989).

How can the apparent erythroid specificity of the HS II enhancer be equated with the presence of tandem AP-1binding sites? As noted above, the polypeptides present in the complex formed on these sites may differ in various cells. Recent data suggest that there is an erythroid-specific DNA-binding protein, designated NF-E2, that binds to a sequence, GCTGAGTCA, which contains the AP-l consensus sequence (Mignotte et al. 1989a,b). An NF-E2-binding site is required for inducibility of the porphobilinogen gene erythroid promoter in MEL cells. The sequence identified as being required for NF-E2 binding is present in the HS II enhancer. The potential role for NF-E2 in the apparent erythroid specificity of the HS II enhancer can only be a matter of speculation at present.

The c-jun and c-fos genes are among a class, designated as early response genes, that is part of the immediate response of various cells to hormone or serum stimulation. These genes appear to be components of a general signaling system used to regulate specific genes in various cell types (Curran and Franza 1988). The c-fos gene is expressed at high levels in late-stage erythroblasts (Caubet et al. 1989). The c-fos, c-iun, and jun-B genes have been shown to be expressed in K562 cells in response to transforming growth factor $\beta$ (Pertovaara et al. 1989). We have preliminary data that hemin stimulation results in increases in c-jun and c-fos mRNA levels in K562 cells ( $R$. Redner, pers. comm.). Also of interest will be the effect of the physiological regulator erythropoietin on expression of these genes in normal erythroid cells.

There is precedence for the importance of AP-1binding sites in enhancer function. c-Jun and c-Fos, as part of the early response to various stimuli, allow AP-1binding sites to confer inducibility on promoter function (Angel et al. 1987; Lee et al. 1987). Functionally important AP-1-binding sites have been found in the enhancers of the chicken $\beta$-globin (Reitman and Felsenfeld 1988), metallothionein II (Lee et al. 1987), and collagenase genes (Angel et al. 1987), and the enhancer of a strain of polyomavinus (Dynan 1989). Mutation of the chicken $\beta$-globin enhancer AP-1-binding site reduces enhancer activity to $10 \%$ of wild type. The structure of this enhancer, like the HS II enhancer, appears to be rela- tively simple. Two footprinted regions, one including the AP-1 site and the other consisting of two Eryf-1 sites (the chicken equivalent of NF-E1), are sufficient for positive regulation by the chicken $\beta$-globin enhancer. The role of this AP-1 site in maturational induction of the chicken $\beta$-like globin genes is unknown. This AP-1 site is relatively inactive alone, but a concatamer of three has 60 -fold enhancing activity.

It has been shown recently that efficient trans-activation of a CAT reporter plasmid by Jun-B requires two or more adjacent AP-1 sites (Chiu et al. 1989). We speculate that the close spacing of AP-1 sites in the human HS II enhancer allows formation of a unique, highly active complex. Hemin induction of K562 cells appears to lead to complex formation on the enhancer and a dramatic increase in activity. Whether this is due to changes in the concentration of proteins available to bind the enhancer or to other changes favoring complex formation is unresolved.

How could the HS II enhancer influence the level of expression of individual globin genes during development and erythroid maturation? It is located nearly 11 $\mathrm{kb}$ from the nearest gene $\epsilon$ and $>50 \mathrm{~kb}$ from the most distal $(\beta)$. We envision a model whereby a loop structure is formed that brings the enhancer and individual promoters into close proximity through operation of selector elements analogous to the model proposed by Choi and Engel (1988). In this model, enhancer action on selected promoters at various stages of development depends on the protein and DNA interactions that result in formation of a particular loop structure bringing the enhancer in proximity to the transcription initiation complex.

\section{Methods}

\section{DNA construction}

Reporter plasmid pUC007, a pUC-based plasmid with a novel polylinker, was used as the vector in these constructions. pUC007 consists of the following polylinker subcloned into the HindIII and EcoRI sites of pUC9: XhoI, BglII, XbaI, HindIII, SmaI, BamHI, ApaI, SphI, and SalI. The $\gamma$-globin promoter was subcloned as a HinfI $\mid-260$ relative to the cap site $|-A l u I|+36)$ fragment into the BgIII and HindIII sites of pUC007 /via an intermediate subcloning step into the HincII site of pUC9). The coding region of the firefly luciferase gene (pSV232A-LA85'; DeWet et al. 1987) was then linked 3' to the $\gamma$-globin promoter as a HindIII-BamHI fragment in pUC007. This enhancerless plasmid was used to establish the level of reporter gene expression with a $\gamma$-globin promoter alone. An XhoI-AatII fragment

Figure 7. Gel mobility-shift assays of the HS II enhancer. $(A)$ An Spl probe from SV40 was used to standardize uninduced and induced K562 nuclear extracts (lanes 1 and 2). The relative Spl-binding activity is shown at top. A 46-bp oligonucleotide consisting of HS II sequence (880-926), including the enhancer (896-916), was used as probe with increasing concentrations of uninduced and induced K562 nuclear extracts (lanes 3-13). (B) The HS II enhancer-containing probe described above was used as probe with $4.4 \mu \mathrm{g}$ of uninduced or induced K562 nuclear extracts. Synthetic oligonucleotides were used as unlabeled competitors in 200 -fold excess. The NF-E1 competitor is described in Methods. The AP-1 competitors were derived from the collagenase gene and SV40 and metallothionein II gene enhancers. (C) The HS II enhancer-containing probe (HS II) described above and a single AP-1 site-containing probe (AP-1) were compared in alternate lanes. The latter was derived from region II of the chicken $\beta$-globin enhancer. These probes were studied against a panel of nuclear extracts (3-5 $\mu \mathrm{g}$ per reaction) and in vitro-synthesized c-Jun (rat) and c-Fos (rat). The nuclear extracts were made from K562-uninduced (K562U) or K562-induced (K562I) cells, MEL cells, HeLa cells, and COS cells, a monkey kidney cell line. Reticulocyte lysate without added RNA (NA) served as a control for in vitro-synthesized c-Jun and c-Fos. 
Ney et al.
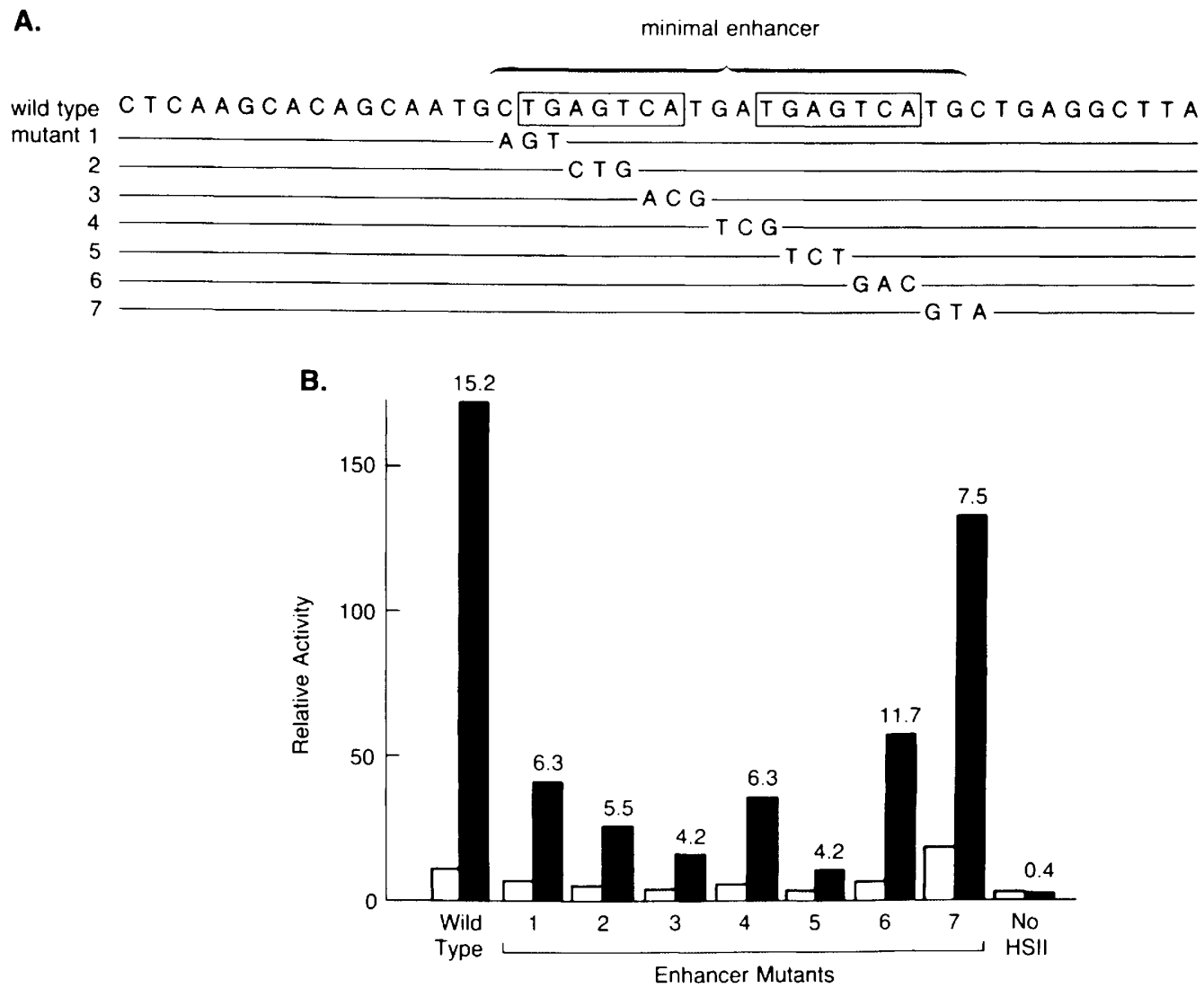

Figure 8. Scanning mutants of the HS II enhancer. The wild-type and mutant enhancers were synthesized as 46-bp oligonucleotides, subcloned into the reporter plasmid, and assayed for enhancing activity. (A) The wild-type 46-bp fragment containing the HS II enhancer is shown at top. Tandem AP-1-binding sites are boxed. Seven mutants scanning the enhancer in 3-bp intervals are shown beneath the 46-bp wild-type sequence. Only mutant 7 falls completely outside both AP-1-binding sites. $(B)$ Activity of the wild-type and mutant enhancers is shown relative to an enhancerless reporter plasmid (no HS II) in uninduced (open bars) and induced (solid bars) K562 cells. The fold increase with induction is shown for the wild-type and mutant enhancers over the solid bars. Each was assayed in duplicate and normalized based on the activity of a cotransfected B19-CAT reporter construct as an internal control.

of this plasmid containing the chimeric $\gamma$-globin promoter/luciferase gene, was subcloned into the SalI and AatII sites of pUC007, $3^{\prime}$ of various mutants of HS II. This strategy allowed for the rapid construction and testing of mutants of HS II.

Truncation mutants of $H S I I$ HS II was subcloned as a KpnI (blunted)-BglII fragment into the BglII (blunted) and BamHI sites of pUC007 (pUC007-HS II). Truncation mutants of HS II were made by exonuclease III digestion from either the $5^{\prime}$ or $3^{\prime}$ end of HS II. A modification of the Erase-a-Base protocol (Promega) was used. Truncations ( $\left.3^{\prime}\right)$ were made as follows: $40 \mu \mathrm{g}$ of pUC007-HS II DNA was linearized at the SalI site, phenol/ chloroform-extracted, ethanol-precipitated, and resuspended in $450 \mu \mathrm{l}$ of buffer [ $66 \mathrm{~mm}$ TrisHCl and $0.66 \mathrm{mM} \mathrm{MgCl}$ (pH 8.0)]. The linearized DNA was digested with 3000 units of exonuclease III at $32^{\circ} \mathrm{C}$ for $6 \mathrm{~min}$. At 30 -sec intervals, 36- $\mu \mathrm{l}$ aliquots (12 total) were taken and added to $108 \mu \mathrm{l}$ of S1 buffer with 30 units of S1 nuclease, on ice. The samples were incubated with $\mathrm{S} 1$ nuclease at $25^{\circ} \mathrm{C}$ for $30 \mathrm{~min}$. S1 nuclease was inactivated by the addition of $14 \mu \mathrm{l}$ of $\mathrm{S} 1$ stop buffer and incubation at $70^{\circ} \mathrm{C}$ for $10 \mathrm{~min}$. To blunt the truncated ends, $14 \mu \mathrm{l}$ of Klenow buffer, containing 2.5 units of Klenow DNA polymerase and $14 \mu \mathrm{l}$ of $0.125 \mathrm{mM}$ dATP, dCTP, dGTP, and dTTP, was added. The DNA was purified by using Gene Clean (Bio 101) and digested with XhoI. The 3 '-truncated HS II fragments were then gel-purified and subcloned as an Xhol-blunted fragment into pUC007 opened at the XhoI and SmaI sites. The extent of $3^{\prime}$ truncation was determined precisely by sequencing. Truncation mutants $\left(5^{\prime}\right)$ were made in the same way, except pUC007-HS II was initially opened at the $X h o l$ site and truncation mutants were subcloned as a Sall-blunted fragment into pUC007 opened at SalI and SmaI. The extent of the $5^{\prime}$ truncation was determined by restriction mapping.

Scrambled enhancer construct An enh- version of HS II was made by replacing 16 of the $20 \mathrm{bp}$ of the enhancer with polylinker from a 3' truncation mutant of HS II. An oligonucleotide was synthesized (924-974), consisting of wild-type HS II sequence from 932 to 974 , with HindIII and XhoI sites on the $5^{\prime}$ end and an EcoRI site on the $3^{\prime}$ end. This oligonucleotide was subcloned into the HindIII and EcoRI sites of pUC9, sequenced, and cut out again as an XhoI-AatII fragment. This fragment was subcloned into the Sall and AatII sites of pUC007 downstream of a $3^{\prime}$ truncation mutant, consisting of wild-type HS II sequence from nucleotide 1 to 900 and a polylinker sequence from 901 to 923 . This plasmid was opened at PpuMl and AatII, and a wild-type HS II sequence from 975 to 1455 was subcloned in as a PpuM1-AatII fragment. This construct effectively replaced wild-type HS II sequence 901-931 with polylinker. 


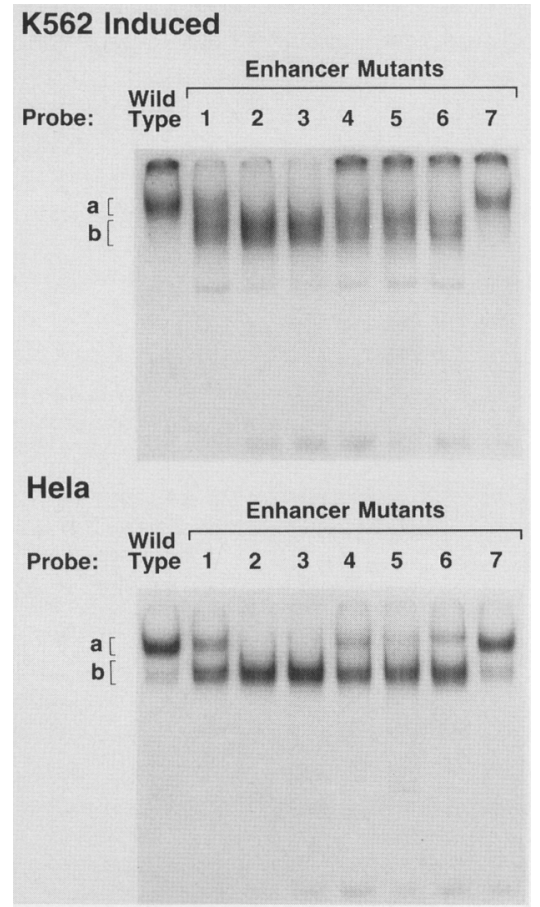

Figure 9. Gel mobility-shift assays of enhancer mutants. Assays were done by use of the wild-type and mutant enhancer probes, as described in the legend to Fig. 8, in conjunction with induced $\mathrm{K} 562$ nuclear extract $(4.7 \mu \mathrm{g}$, top) or HeLa cell nuclear extract $(3.4 \mu \mathrm{g}$, bottom).

\section{Oligonucleotides}

Oligonucleotides were synthesized on an Applied Biosystems DNA Synthesizer model 380B, by use of phosphoramidite chemistry. The oligonucleotides were purified on OPC cartridges (Applied Biosystems). Prior to subcloning or use as competitors, complementary strands were annealed in a buffer of 10 $\mathrm{mM}$ Tris- $\mathrm{HCl}\langle\mathrm{pH} \mathrm{7.5}\rangle, 50 \mathrm{mM} \mathrm{NaCl}$, and $10 \mathrm{mM} \mathrm{MgCl}_{2}$ by heating to $95^{\circ} \mathrm{C}$ for $2 \mathrm{~min}$ and cooling to room temperature for $>1 \mathrm{hr}$. Oligonucleotides were made with $5^{\prime}$ HindIII and $3^{\prime}$ BamHI ends. They were subconed into these sites of pUC007 and sequenced by the chain-termination method (Sequenase, U.S. Biochemical) (Smith 1980). The chimeric $\gamma$-globin promoter/luciferase reporter gene was inserted into the Sall and AatII sites of these plasmids as an XhoI-AatII fragment.

\section{Tissue culture and cell transfections}

Human erythroleukemia K562 cells and adherent HeLa cells were grown in improved minimal essential medium (IMEM, Biofluids) with $10 \%$ fetal calf serum. Plasmid DNA was prepared by Triton X-100 lysis and purification over two cesium chloride gradients. Plasmid DNA was introduced into K562 cells in log phase growth by electroporation (Potter et al. 1984) by use of a Bio-Rad gene pulser apparatus. Adherent HeLa cells were transfected by the calcium phosphate precipitation method (Wigler et al. 1978). A constant amount of an internal control plasmid, B19-CAT (a gift from T. Shimada), containing the B19 parvovirus promoter driving the bacterial CAT gene, was included in all transfections to normalize the luciferase data. To transfect $\mathrm{K} 562$ cells, $4.0 \times 10^{7}$ cells were mixed with a total of $40 \mu \mathrm{g}$ of supercoiled plasmid DNA in a final volume of $400 \mu \mathrm{l}$ and electroporated at settings of $0.20 \mathrm{~V}$ and $960 \mu \mathrm{F}$. The
$40 \mu \mathrm{g}$ of plasmid consisted of $32 \mu \mathrm{g}$ of test plasmid and $8 \mu \mathrm{g}$ of B19-CAT. HeLa cells were transfected with $16 \mu \mathrm{g}$ of the luciferase reporter construct and $4 \mu \mathrm{g}$ of B19-CAT. Forty-eight hours after transfection, cells were harvested, and transient assays were performed. Hemin induction $(20 \mu \mathrm{M})$ was initiated $24 \mathrm{hr}$ prior to transfection and continued for $48 \mathrm{hr}$ afterward for a total of $72 \mathrm{hr}$ (Lloyd et al. 1989).

\section{Transient assays}

Luciferase activity was measured (deWet et al. 1987; Nelson et al. 1988) on a Monolight 2001 luminometer (Analytical Luminescence Laboratories). The luciferase assay was linear from 1000 to 100,000 light units. Samples giving values $>100,000$ light units were diluted, reassayed, and corrected for dilution by the appropriate factor. CAT activity was determined by a scintillation vial assay (Neumann et al. 1987) by use of $\left[{ }^{14} \mathrm{C}\right.$ )-butyryl Coenzyme A (New England Nuclear) as substrate.

\section{Primer extension assay}

Primer extension off of the $\gamma$-globin primer (CCTCCTCTGTGAAATGACCCATGGC) or the luciferase primer (GATGTTCACCTCGATATGTGC) was performed according to the method of Phelps and Howley (1987).

\section{Analysis of DNA-binding proteins}

Nuclear extracts Cells were cultured in suspension in microcarrier flasks (Wheaton) and harvested in late log phase. Extracts were prepared by the method of Dignam (Dignam et al. 1983), in the presence of PMSF, aprotinin, pepstatin, and leupeptin. The extract was dialyzed against a buffer (buffer D) composed of $20 \mathrm{~mm}$ HEPES (pH 7.8), $100 \mathrm{~mm} \mathrm{KCl}, 0.2 \mathrm{mM}$ EDTA, $0.5 \mathrm{~mm}$ DTT, $0.5 \mathrm{~mm}$ PMSF, and $20 \%$ glycerol and stored in small aliquots at $-70^{\circ} \mathrm{C}$. Protein concentration was determined by the Bradford method (Bradford 1976), with a kit from Bio-Rad and bovine serum albumin as a standard. The protein concentration was generally $5-6 \mathrm{mg} / \mathrm{ml}$. Hemin-induced $\mathrm{K} 562$ nuclear extracts were prepared by the addition of hemin to the culture medium ( $20 \mu \mathrm{M}$ final concentration) $36 \mathrm{hr}$ prior to harvest.

In vitro-synthesized c-Jun (rat) and c-Fos (rat) c-Jun and c-Fos were provided by Frank Rauscher and Tom Curran. The in vitro association of c-Jun and c-Fos and reaction conditions for gel mobility-shift assay have been described by Rauscher et al. (1988).

DNase I protection assay Probes for the DNase I protection assay were made from pUC007-HS II and pUC007-HS II enh ${ }^{-}$. These plasmids were linearized at PpuM1 (974) and end-labeled with polynucleotide kinase (lower strand) or Klenow DNA polymerase (upper strand). The probe was released by digestion with HindIII and purified from agarose by Gene Clean.

Each footprint reaction (Jones et al. 1985) contained 10,000 cpm of end-labeled probe, varying amounts of nuclear extract, and $1 \mu \mathrm{g}$ of poly[d(I-C)], in a volume of $30 \mu \mathrm{l}$. The final ionic composition was $20 \mathrm{mM}$ HEPES (pH 7.8), $60 \mathrm{mM} \mathrm{KCl}, 0.2 \mathrm{mM}$ EDTA, $1.3 \mathrm{mM} \mathrm{MgCl}_{2}, 0.5 \mathrm{~mm}$ DTT, $10 \%$ glycerol, and $6 \%$ polyethylene glycol (avg. $M_{\mathrm{r}} 8000$ ). The reaction was incubated at $4^{\circ} \mathrm{C}$ for $15 \mathrm{~min}$, followed by $25^{\circ} \mathrm{C}$ for $15 \mathrm{~min}$. After adding $\mathrm{CaCl}_{2}$ and $\mathrm{MgCl}_{2}$ to a final concentration of $3 \mathrm{~mm}$, DNase I digestion was performed at $25^{\circ} \mathrm{C}$ for $1 \mathrm{~min}$. The amount of DNase I used in each reaction was the amount needed to give equivalent degrees of probe digestion. The reaction was termi- 
nated with a stop buffer containing EDTA, SDS, and proteinase $\mathrm{K}$. Proteinase $\mathrm{K}$ digestion proceeded at $37^{\circ} \mathrm{C}$ for $30 \mathrm{~min}$. The samples were then extracted twice with phenol/chloroform, precipitated twice with ethanol, and analyzed on a $5 \%$ sequencing gel.

In situ phenanthroline/copper footprinting After gel mobility-shift assay, as described below, in situ phenanthroline/ copper footprinting was performed according to the method of Kuwabara and Sigman (1987).

Gel mobility-shift assay The HS II enhancer and chicken $\beta$ enhancer probes were prepared from oligonucleotides subcloned into pUC007, released by HindIII and BamHI digestion, labeled with Klenow DNA polymerase, and purified over $12 \%$ acrylamide gels. The SV40 (Sp1) probe was provided by Todd Evans and Gary Felsenfeld. Gel mobility-shift assays were performed (Fried and Crothers 1981; Strauss and Varshavsky 1984) with $20,000 \mathrm{cpm}$ of probe added last to a $20-\mu$ l reaction containing varying amounts of nuclear extracts and $1 \mu \mathrm{g}$ of poly[d(I-C)]. The final ionic conditions were identical to the footprint assay, with the exception of $6 \mathrm{mM} \mathrm{MgCl}$. Doublestranded synthetic oligonucleotides were used as cold competitors in some reactions and were added with the probe. A 1000 -fold excess of self-competitors and 200 -fold excess of AP-1 competitors were used. After incubation at $25^{\circ} \mathrm{C}$ for $30 \mathrm{~min}$, the samples were run on a $4 \%$ nondenaturing acrylamide gel in $0.25 \times$ Tris-borate-EDTA buffer for $90 \mathrm{~min}$ at $10 \mathrm{~V} / \mathrm{cm}$. The gels were dried and exposed to film for $\sim 6 \mathrm{hr}$.

Probes The single AP-1 site probe was derived from region II of the chicken $\beta$-globin enhancer (Mignotte et al. 1989b). AP-1- and Spl-binding sites are underlined.

HS II enhancer (AP-1):

Chicken $\beta$-globin enhancer (AP-1):

SV40 (Sp 1):

$$
\begin{aligned}
& \text { CTCAAGCACAGCAATGCTGAGTC } \\
& \text { ATGATGAGTCATGCTGAGGCTTA } \\
& \text { TCCCCAAGGAGCTGAC } \\
& \text { TCATGCTAGCCCAGCAG } \\
& \text { AATTGCAGAGCTGGGAATCCTAACT }
\end{aligned}
$$$$
\text { GGGCGGAGTTATGCTGGTGGT } \bar{T} \text { TGG }
$$

Competitors The NF-El competitor consisted of the -199 to -163 region of $\gamma$-globin gene promoter that contains a $\mathrm{T} \rightarrow \mathrm{C}$ substitution at position -175 . This region contains two binding sites for NF-E1 and one for the octamer-binding protein. The $-175 \mathrm{~T} \rightarrow \mathrm{C}$ mutation ablates octamer binding but leaves NF-El binding intact (Tsai et al. 1989). Only the AP-1 consensus sequence and 1 nucleotide on either side matches the actual sequence of the collagenase gene enhancer. AP-1and NF-E1-binding sites are underlined.

$\begin{array}{lc}\text { Collagenase gene enhancer }\{\text { AP-1 }): & \text { AGCTTATCGATTT } \\ \text { SV40 enhancer (AP-1): } & \text { GATGAGTCAGCCG } \\ \text { Metallothionein II (AP-1): } & \text { AGCTTATCTCAA } \\ -175 \mathrm{~T} \rightarrow \mathrm{C} \gamma \text {-globin promoter (NF-E1): } & \text { AGCTTCGCGCTCAGCAAG } \\ & \text { GATGCGCGCTCACTCACG } \\ & \text { TTCCCACACTATCTCAAT } \\ \text { GCAAACATCTGTCTGAAA }\end{array}$

\section{Acknowledgments}

We thank David Bodine for providing pUC007, Chris Lowrey for providing the K562 and MEL cell nuclear extracts, Amanda Cline for the $5^{\prime}$ truncations of HS II, Frank Rauscher and Tom Curran for in vitro-synthesized c-Jun and c-Fos, and Todd Evans and Gary Felsenfeld for the SV40 $(S p 1)$ probe. We also thank David Bodine and Robert Redner for their critical reading of the manuscript. We are grateful to David Trauber for first pointing out the AP-1-binding sequences in the enhancer.

\section{References}

Angel, P., I. Baumann, B. Stein, H. Delius, H.J. Rahmsdorf, and P. Herrlich. 1987. 12-O-Tetradecanoyl-phorbol-13-acetate induction of the human collagenase gene is mediated by an inducible enhancer element located in the $5^{\prime}$-flanking region. Mol. Cell. Biol. 7: 2256-2266.

Antoniou, M., E. deBoer, G. Habets, and F. Grosveld. 1988. The human $\beta$-globin gene contains multiple regulatory regions: Identification of one promoter and two downstream enhancers. EMBO I. 7: 377-384.

Bartha, E., E. Olah, J.G. Szelenyi, and S.R. Hollan. 1987. Characterization of "fetal-type" acetylcholinesterase in hemintreated K562 cell cultures. Blood Cells 12: 647-655.

Behringer, R.R., R.E. Hammer, R.L. Brinster, R.D. Palmiter, and T.M. Townes. 1987. Two 3' sequences direct adult erythroid-specific expression of human $\beta$-globin genes in transgenic mice. Proc. Natl. Acad. Sci. 84: 7056-7060.

Blom van Assendelft, G., O. Hanscombe, F. Grosveld, and D.R. Greaves. 1989. The $\beta$-globin dominant control region activates homologous and heterologous promoters in a tissuespecific manner. Cell 56: 969-977.

Bodine, D.M. and T.J. Ley. 1987. An enhancer element lies 3' to the human A $_{\gamma}$ globin gene. EMBO /. 6: 2997-3004.

Bohmann, D., T.J. Bos, A. Admon, T. Nishimura, P.K. Vogt, and R. Tjian. 1987. Human proto-oncogene c-jun encodes a DNA binding protein with structural and functional properties of transcription factor AP-1. Science 238: 1386-1392.

Bradford, M.M. 1976. A rapid and sensitive method for the quantitation of microgram quantities of protein using the principle of protein-dye binding. Anal. Biochem. 72: 248254.

Catala, F., E. deBoer, G. Habets, and F. Grosveld. 1989. Nuclear protein factors and erythroid transcription of the human $\mathbf{A}_{\boldsymbol{\gamma}}$. globin gene. Nucleic Acids Res. 17: 3811-3827.

Caubet, J.F., M.T. Mitjavila, A. Dubart, D. Roten, S.C. Weil, and W. Vainchenker. 1989. Expression of the c-fos proto-oncogene by human and murine erythroblasts. Blood 74: $947-$ 951 .

Chao, M.V., P. Mellon, P. Charney, T. Maniatis, and R. Axel. 1983. The regulated expression of $\beta$-globin genes introduced into mouse erythroleukemia cells. Cell 32: 483-493.

Chiu, R., P. Angel, and M. Karin. 1989. Jun-B differs in its biological properties from, and is a negative regulator of, $\mathrm{c}$-jun. Cell 59: 979-986.

Choi, O.R. and J.D. Engel. 1988. Developmental regulation of $\beta$-globin gene switching. Cell 55: 17-26.

Cohen, D.R., P.C. Ferreira, R. Gentz, B.R. Franza Jr., and T. Curran. 1989. The product of a fos-related gene, fra-1, binds cooperatively to the AP-1 site with Jun: transcription factor AP-1 is comprised of multiple protein complexes. Genes Dev. 3: $173-184$.

Curran, T. and B.R. Franza Jr. 1988. Fos and Jun: The AP-1 connection. Cell 55: 395-397.

Curtin, P., M. Pirastu, Y.W. Kan, J.A. Gobert-Jones, A.D. Stephens, and H. Lehmann. 1985. A distant gene deletion affects $\beta$-globin gene function in an atypical $\gamma \delta \beta$-thalassemia. I. Clin. Invest. 76: 1554-1558.

Curtin, P., D. Lui, W. Lui, J. Chang, and Y.W. Kan. 1989. Human $\beta$-globin gene expression in transgenic mice is enhanced by a distant DNase I hypersensitive site. Proc. Natl. Acad. Sci. 86: 7082-7086.

Dean, A., T.J. Ley, R.K. Humphries, M. Fordis, and A.N. 
Schechter. 1983. Inducible transcription of five globin genes in K562 human leukemia cells. Proc. Natl. Acad. Sci. 80: $5515-5519$.

deBoer, E., M. Antoniou, V. Mignotte, L. Wall, and F. Grosveld. 1988 . The human $\beta$-globin promoter; nuclear protein factors and erythroid specific induction of transcription. $E M B O F$. 7: 4203-4212.

deWet, J.R., K.V. Wood, M. DeLuca, D.R. Helinski, and S. Subramani. 1987. Firefly luciferase gene: Structure and expression in mammalian cells. Mol. Cell. Biol. 7: 725-737.

Dignam, J.D., R.M. Lebovitz, and R.G. Roeder. 1983. Accurate transcription initiation by RNA polymerase II in a soluble extract from isolated mammalian nuclei. Nucleic Acids Res. 11: $1475-1489$.

Donovan-Peluso, M., S. Acuto, M. Swanson, C. Dobkin, and A. Bank. 1987. Expression of human $\gamma$-globin genes in human erythroleukemia (K562) cells. I. Biol. Chem. 262: 1705117057.

Driscoll, C., C.S. Dobkin, and B.P. Alter. 1989. Gamma/delta/ beta thalassemia due to a de novo mutation deleting the $5^{\prime} \beta$ globin gene locus activating region hypersensitive sites. Proc. Natl. Acad. Sci. 86: 7470-7474.

Dynan, W.S. 1989. Modularity in promoters and enhancers Cell 58: 1-4

Forrester, W.C., U. Novak, R. Gelinas, and M. Groudine. 1989 Molecular analysis of the human $\beta$-globin locus activation region. Proc. Natl. Acad. Sci. 86:5439-5443.

Forrester, W.C., S. Takegawa, T. Papayannopoulou, G. Stamatoyannopoulos, and M. Groudine. 1987. Evidence for a locus activation region: The formation of developmentally stable hypersensitive sites in globin-expressing hybrids. Nucleic Acids Res. 15: 10159-10177.

Forrester, W.C., C. Thompson, J.T. Elder, and M. Groudine. 1986. A developmentally stable chromatin structure in the human $\beta$-globin gene cluster. Proc. Natl. Acad. Sci. 83: $1359-1363$.

Fried, M. and D.M. Crothers. 1981. Equilibria and kinetics of lac repressor-operator interactions by polyacrylamide gel electrophoresis. Nucleic Acids Res. 9: 6506-6525.

Gentz, R., F.J. Rauscher III, C. Abate, and T. Curran. 1989. Parallel association of fos and jun leucine zippers juxtaposes DNA binding domains. Science 243: 1695-1699.

Grosveld, F., G. Blom van Assendelft, D.R. Greaves, and G. Kollias. 1987. Position-independent, high-level expression of the human $\beta$-globin gene in transgenic mice. Cell 51: 975-985.

Groudine, M., T. Kohwi-Shigematsu, R. Gelinas, G. Stamatoyannopoulos, and T. Papayannopoulou. 1983. Human fetal to adult hemoglobin switching: Changes in chromatin structure of the $\beta$-globin gene locus. Proc. Natl. Acad. Sci. 80: $7551-7555$.

Gumucio, D.L., K.L. Rood, T.A. Gray, M.F. Riordan, C.I. Sartor, and F.S. Collins. 1988. Nuclear proteins that bind the human $\gamma$-globin gene promoter: alterations in binding produced by point mutations associated with hereditary persistence of fetal hemoglobin. Mol. Cell. Biol. 8: 5310-5322.

Halazonetis, T.D., K. Georgopoulos, M.E. Greenberg, and P. Leder. 1988. c-Jun dimerizes with itself and with c-Fos, forming complexes of different DNA binding affinities. Cell 55: $917-924$

Hirai, S.I., R.P. Ryseck, F. Mechta, R. Bravo, and M. Yaniv. 1989. Characterization of junD: A new member of the jun proto-oncogene family. EMBO I. 8: 1433-1439.

Hoffman, R., N. Ibrahim, M.J. Murnane, A. Diamond, B.G. Forget, and R.D. Levere. 1980. Hemin control of heme biosynthesis and catabolism in a human leukemia cell line.
Blood 56: $567-570$.

Jackson, P.D., T. Evans, J.M. Nickol, and G. Felsenfeld. 1989. Developmental modulation of protein binding to $\beta$-globin gene regulatory sites within chicken erythrocyte nuclei. Genes Dev. 3: 1860-1873.

Jones, K.A., K.R. Yamamoto, and R. Tjian. 1985. Two distinct transcription factors bind to the HSV thymidine kinase promoter in vitro. Cell 42: 559-572.

Jones, N.C., P.W. Rigby, and E.B. Ziff. 1988. Trans-acting protein factors and the regulation of eukaryotic transcription: Lessons from studies on DNA tumor viruses. Genes Dev. 2: $267-281$.

Karlsson, S. and A.W. Nienhuis. 1985. Developmental regulation of human globin genes. Annu. Rev. Biochem. 54: $1071-1108$.

Kioussis, D., E. Vanin, T. deLange, R.A. Flavell, and F.G. Grosveld. 1983. $\beta$-Globin gene inactivation by DNA translocation in $\gamma \beta$-thalassemia. Nature 306: 662-666.

Kioussis, D., F. Wilson, K. Khazaie, and F. Grosveld. 1985. Differential expression of human globin genes introduced in K562 cells. EMBO I. 4: 927-931.

Kollias, G., N. Wrighton, J. Hurst, and F. Grosveld. 1986. Regulated expression of human $\hat{A}_{\gamma-}, \beta-$, and hybrid $\gamma \beta$-globin genes in transgenic mice: Manipulation of the developmental expression patterns. Cell 46:89-94.

Kollias, G., J. Hurst, E. deBoer, and F. Grosveld. 1987. The human betaglobin gene contains a downstream developmental specific enhancer. Nucleic Acids Res. 15: 57395747.

Kouzarides, T. and E. Ziff. 1989. Leucine zippers of fos, jun and GCN4 dictate dimerization specificity and thereby control DNA binding. Nature 340: 568-571.

Kuwabara, M.D. and D.S. Sigman. 1987. Footprinting DNAprotein complexes in situ following gel retardation assays using 1,10-phenanthroline/copper ion: Escherichia coli RNA polymerase-lac promoter complexes. Biochemistry 26: $7234-7238$.

Lee, W., A. Haslinger, M. Karin, and R. Tjian. 1987. Activation of transcription by two factors that bind promoter and en hancer sequences of the human metallothionein gene and SV40. Nature 325: 368-372.

Lin, H.J., N.P. Anagnou, T.R. Rutherford, T. Shimada, and A.W. Nienhuis. 1987. Activation of the human $\beta$-globin promoter in $\mathrm{K} 562$ cells by DNA sequences $5^{\prime}$ to the fetal $\gamma$ - or embryonic $\zeta$-globin genes. I. Clin. Invest. 80: 374-380.

Lloyd, J.A., R.F. Lee, and J.B. Lingrel. 1989. Mutations in two regions upstream of the ${ }^{{ }^{\gamma} \gamma}$ globin gene canonical promoter affect gene expression. Nucleic Acids Res. 17: 4339-4352.

Lozzio, C.B. and B.B. Lozzio. 1975. Human chronic myelogenous leukemia cell-line with positive Philadelphia chromosome. Blood 45: 321-334.

Magram, J., K. Chada, and F. Costantini. 1985. Developmental regulation of a cloned adult $\beta$-globin gene in transgenic mice. Nature 315: 338-340.

Mantovani, R., N. Malgaretti, S. Nicolis, B. Giglioni, P. Comi, N. Cappellini, M.T. Bertero, F. Caligaris-Cappio, andd S. Ottolenghi. 1988a. An erythroid specific nuclear factor binding to the proximal CACCC box of the $\beta$-globin gene promoter. Nucleic Acids Res. 16: 4299-4313.

Mantovani, R., N. Malgaretti, S. Nicolis, A. Ronchi, B. Giglioni, and S. Ottolenghi. 1988b. The effects of HPFH mutations in the human gamma-globin promoter on binding of ubiquitous and erythroid specific nuclear factors. Nucleic Acids Res. 16: $7783-7797$.

McGinniss, M.H. and A. Dean. 1985. Expression of red cell antigens by K562 human leukemia cells before and after in- 
duction of hemoglobin synthesis by hemin. Transfusion 25: 105-109.

Mignotte, V., J.F. Eleouet, N. Raich, and P.H. Romeo. 1989a. Cis- and transacting elements involved in the regulation of the erythroid promoter of the human porphobilinogen deaminase gene. Proc. Natl. Acad. Sci. 86: 6548-6552.

Mignotte, V., L. Wall, E. deBoer, F. Grosveld, and P.H. Romeo. $1989 \mathrm{~b}$. Two tissue-specific factors bind the erythroid promoter of the human porphobilinogen deaminase gene. $\mathrm{Nu}$ cleic Acids Res. 17: 37-54.

Mitchell, P.J. and R. Tjian. 1989. Transcriptional regulation in mammalian cells by sequence-specific DNA binding proteins. Science 245: 371-378.

Nelson, C., V.R. Albert, H.P. Elsholtz, L.I.W. Lu, and M.G. Rosenfeld. 1988. Activation of cell-specific expression of rat growth hormone and prolactin genes by a common transcription factor. Science 239: 1400-1405.

Neumann, J.R., C.A. Morency, and K.O. Russian. 1987. A novel rapid assay for chloramphenicol acetyltransferase gene expression. BioTechniques 5: 444-447.

Pertovaara, L., L. Sistonen, T.J. Bos, P.K. Vogt, J. Keski-Oja, and K. Alitalo. 1989. Enhanced jun gene expression is an early genomic response to transforming growth factor beta stimulation. Mol. Cell. Biol. 9: 1255-1262.

Phelps, W.C. and P.M. Howley. 1987. Transcriptional trans-activation by the human papillomavirus type 16 E2 gene product. J. Virol. 61: 1630-1638.

Potter, H., L. Weir, and P. Leder. 1984. Enhancer-dependent expression of human $\kappa$-immunoglobulin genes introduced into mouse pre-B lymphocytes by electroporation. Proc. Natl. Acad. Sci. 81: 7161-7165.

Ransone, L.J., J. Visvader, P. Sassone-Corsi, and I.M. Verma. 1989. Fos-jun interaction: Mutational analysis of the leucine zipper domain of both proteins. Genes Dev. 3: 770781.

Rauscher, F.J., III, P.J. Voulalas, B.R. Franza Jr., and T. Curran. 1988. Fos and jun bind cooperatively to the AP-1 site: Reconstitution in vitro. Genes Dev. 2: 1687-1699.

Reitman, M. and G. Felsenfeld. 1988. Mutational analysis of the chicken beta-globin enhancer reveals two positiveacting domains. Proc. Natl. Acad. Sci. 85: 6267-6271.

Rutherford, T. and A.W. Nienhuis. 1987. Human globin gene promoter sequences are sufficient for specific expression of a hybrid gene transfected into tissue culture. Mol. Cell. Biol. 7: 398-402.

Rutherford, T., J.B. Clegg, D.R. Higgs, R.W. Jones, J. Thompson, and D.J. Weatherall. 1981. Embryonic erythroid differentiation in the human leukemic cell line K562. Proc. Nat1. Acad. Sci. 78: 348-352.

Ryan, T.M., R.R. Behringer, N.C. Martin, T.M. Townes, R.D. Palmiter, and R.L. Brinster. 1989. A single erythroid-specific DNase I superhypersensitive site activates high levels of human $\beta$-globin gene expression in transgenic mice. Genes Dev. 3: 314-323.

Smith, A.J.H. 1980. DNA sequence analysis by primed synthesis. Methods Enzymol. 65: 560-580.

Sorrentino, B.P., P.A. Ney, D.M. Bodine, and A.W. Nienhuis. 1990. A 46 base pair enhancer sequence within the locus activating region is required for induced expression of the $\gamma$-globin gene during erythroid differentiation. Nucleic Acids Res. (in press).

Stamatoyannopoulos, G. and A.W. Nienhuis. 1987. Hemoglobin switching. In The molecular basis of blood diseases (ed. G. Stamatoyannopoulos, A. Nienhuis, P. Leder, and P. Majerus), pp. 67-105. W.B. Saunders, Philadelphia.

Strauss, F. and A. Varshavsky. 1984. A protein binds to a satel- lite DNA repeat at three specific sites that would be brought into mutual proximity by DNA folding in the nucleosome. Cell 37: 889-901.

Talbot, D., P. Collis, M. Antoniou, M. Vidal, F. Grosveld, and D.R. Greaves. 1989. A dominant control region from the human $\beta$-globin locus conferring integration site-independent gene expression. Nature 338: 352-355.

Townes, T.M., J.B. Lingrel, H.Y. Chen, R.L. Brinster, and R.D. Palmiter. 1985. Erythroid-specific expression of human $\beta$ globin genes in transgenic mice. EMBO /. 4: 1715-1723.

Trudel, M. and F. Costantini. 1987. A 3 ' enhancer contributes to the stage-specific expression of the human $\beta$-globin gene. Genes Dev. 1: 954-961.

Tsai, S.F., D.I. Martin, L.I. Zon, A.D. D'Andrea, G.G. Wong, and S.H. Orkin. 1989. Cloning of cDNA for the major DNAbinding protein of the erythroid lineage through expression in mammalian cells. Nature 339:446-451.

Tuan, D. and I.M. London. 1984. Mapping of DNAse I-hypersensitive sites in the upstream DNA of human embryonic epsilon-globin gene in K562 leukemia cells. Proc. Natl. Acad. Sci. 81: 2718-2722.

Tuan, D., W. Solomon, Q. Li, and I.M. London. 1985. The " $\beta$ like-globin" gene domain in human erythroid cells. Proc. Natl. Acad. Sci. 82: 6384-6388.

Tuan, D.Y., W.B. Solomon, I.M. London, and D.P. Lee. 1989. An erythroid-specific, developmental-stage-independent enhancer far upstream of the human "beta-like globin" genes. Proc. Natl. Acad. Sci. 86: 2554-2558.

Turner, R. and R. Tjian. 1989. Leucine repeats and an adjacent DNA binding domain mediate the formation of functional cFos-cJun heterodimers. Science 243: 1689-1694.

Wall, L., E. deBoer, and F. Grosveld. 1988. The human $\beta$-globin gene 3 ' enhancer contains multiple binding sites for an ery. throid-specific protein. Genes Dev. 2: 1089-1100.

Wigler, M., A. Pellicer, S. Silverstein, and R. Axel. 1978. Biochemical transfer of single-copy eucaryotic genes using total cellular DNA as donor. Cell 14: 725-731.

Wright, S., E. deBoer, F.G. Grosveld, and R.A. Flavell. 1983. Regulated expression of the human $\beta$-globin gene family in murine erythroleukaemia cells. Nature 305: 333-336.

Wright, S., A. Rosenthal, R. Flavell, and F. Grosveld. 1984. DNA sequences required for regulated expression of $\beta$ globin genes in murine erythroleukemia cells. Cell 38: 265273. 


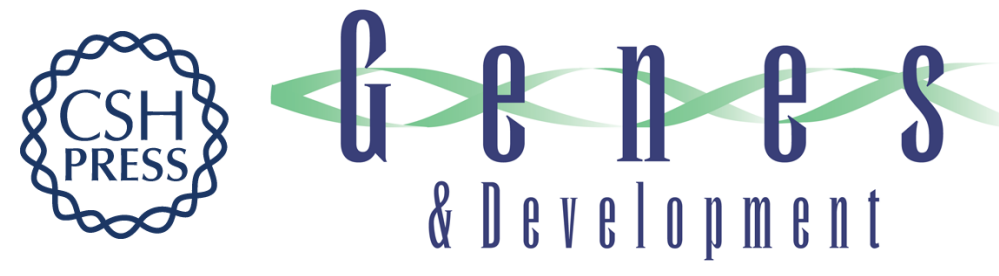

\section{Tandem AP-1-binding sites within the human beta-globin dominant control region function as an inducible enhancer in erythroid cells.}

P A Ney, B P Sorrentino, K T McDonagh, et al.

Genes Dev. 1990, 4:

Access the most recent version at doi:10.1101/gad.4.6.993

References This article cites 81 articles, 36 of which can be accessed free at:

http://genesdev.cshlp.org/content/4/6/993.full.html\#ref-list-1

License

Email Alerting

Service

Receive free email alerts when new articles cite this article - sign up in the box at the top right corner of the article or click here.

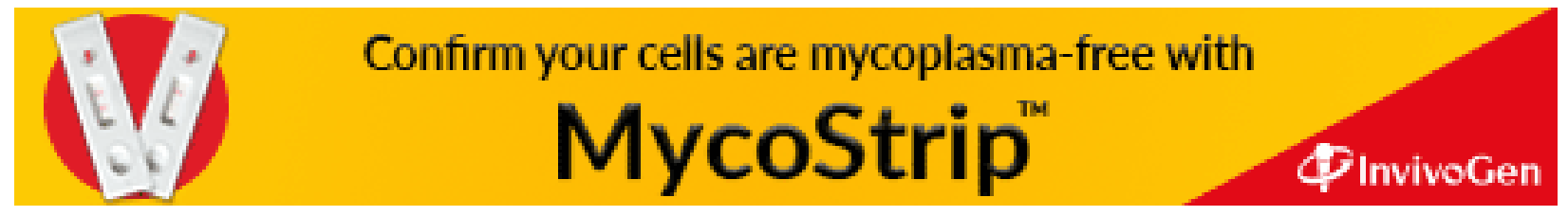

